\title{
Job Satisfaction among Secondary School Teachers: Emotional Intelligence, Occupational Stress and Self-Efficacy as Predictors
}

\author{
Moyosola Jude Akomolafe ${ }^{1 *}$ \\ Abel Olufemi Ogunmakin ${ }^{2}$ \\ 1,2 Department of Guidance and Counselling, Faculty of Education, Adekunle Ajasin University, \\ P.M.B 001, Akungba-Akoko, Ondo State, Nigeria \\ *Email: moyojude@yahoo.com
}

Doi:10.5901/jesr.2014.v4n3p487

\begin{abstract}
In recent years, job satisfaction among Nigerian workers has assumed great importance in the literature on counselling and educational psychology. However, few studies have examined the influence of psychological factors on job satisfaction among secondary school teachers. Thus, this research aims to examine the contributions of emotional intelligence, occupational stress and self-efficacy to job satisfaction secondary school teachers. The correlational type of descriptive research design was used for the study. Four hundred teachers constituted the sample of the study. Four standardized instruments were used to measure both the independent and dependent variables. Two research questions were answered in the study. Through multiple regression analysis the researchers found that emotional intelligence, occupational stress and self-efficacy jointly predicted job satisfaction. Further analysis indicates that emotional intelligence is more important than self-efficacy while occupational stress did not predict job satisfaction among teachers. These results are discussed and counselling and educational psychologists are challenged to assume more responsibility and active role in enhancing emotional intelligence and self-efficacy among secondary school teacher. It is further recommended that counselling, educational psychologist and school administrators should equip teachers with necessary stress management skills.
\end{abstract}

Keywords: Emotional intelligence, occupational stress, self-efficacy, job satisfaction, secondary school teachers.

\section{Introduction}

An educational system that is sound is usually considered to be the bedrock of a developing country. Quality teachers are indispensable for the attainment of such educational system. This high esteem role of teachers has made teaching profession to be extremely challenging and demanding. The situation has forced teachers into a hectic and busy schedule which has made them to experience high level of stress, unhappiness and job dissatisfaction in recent time (Salim, Nasir, Arip \& Mustafa, 2012). One of the job related topics that received greater attention of educational psychologists in Nigeria in the past years is job satisfaction of secondary school teachers. Many studies carried out within the last decades revealed a high rate of job dissatisfaction among teachers (Adeyoju 1999, Ajayi, 1998, 1981; Adeyemo, 1996, 1986). Surprisingly, in recent years, research has reported moderate improvement in the level of job satisfaction among secondary school teachers (Adetayo, 2008; Gesinde \& Adejumo, 2012).

Job satisfaction of employees is very crucial to the success of any organization. It mediates the relationship between working conditions and organizational outcomes (Dormann \& Zapt, 2001; Akomolafe \& Olatomide, 2013). On one hand, job satisfaction enhances organizational commitment, organizational citizenship behaviour and employee wellbeing (Rue \& Byars, 2005; George \& Jones, 2008; Ghazzawi, 2008; Ghazzawi \& Smith, 2009; Robbins \& Judge, 2009; Oyewobi, Suleiman \& Muhammad-Jamil, 2012; Akomolafe \& Olatomide 2013). Teachers who are satisfied with their jobs usually have a high degree of professional competence. They feel qualified in terms of their knowledge of subject matter and teaching skills, and they feel secured about classroom management. The effectiveness of an educational system depends largely on the job satisfaction of teachers employed in the system (Sleyn, 1992).

On the other hand, the consequences of job dissatisfaction are absenteeism from schools, turnover intentions and turnover, aggressive behavior towards colleagues and learners, early exit from the teaching profession and psychological withdrawal from work (George \& Jones 2008; Ghazzawi, 2008; Ghazzawi \& Smith, 2009, Robbins \& Judge, 2009). Some factors reported to be contributing to job satisfaction or dissatisfaction include: salary structure, working conditions, attitude of parents, students' attitudes toward learning, loss of job and lives, promotion, workload and so on (Wright \& 
Davis, 2003; Kim, 2004; Borzaga \& Tortia, 2006).

The above mentioned factors influencing job satisfaction are physical, economical and sociological in nature. Few studies had given attention to the contributions of psychological factors to job satisfaction among secondary school teachers in Nigeria. Therefore, the primary focus of this paper was to determine the contributions of emotional intelligence, occupational stress, and self-efficacy to job satisfaction among secondary school teachers.

\section{Literature Review}

\subsection{The Concept of Job Satisfaction}

Job satisfaction is a pleasurable or positive emotional state resulting from appraisal of one's job or job experiences (Locke, 1976). Job satisfaction has uni-dimensional and multi-dimensional definitions. A uni-dimensional definition provides an overall definition of job satisfaction resulting in measures which are referred to as global measures (Spector, 1997). The multi-dimensional definition provides a more elaborate type of conceptualized and operationalized facets such as satisfaction with pay, promotion, co-workers, nature of work and communication (Spector, 1997, 2000).

Job satisfaction has also been described as a positive emotional state resulting from the characteristics and aspects of a work setting (Arches, 1999). Shahnawaz and Jafri (2009) defines job satisfaction as a pleasurable emotional state resulting from the appraisal of one's job - an effective reaction to one's job and an attitude towards one's job. Khanna (2010) describes job satisfaction as a positive attitude by an employee towards his job as well as his personal life. These definitions demonstrate that job satisfaction involves activities within and outside workplace. Thus, how an individual lives and associates in the environment are directly and indirectly influenced by work settings. Erdogan (1994) even reported that job satisfaction affect employees' physical and mental health, the working and efficiency of the organization, comfort, economic development, disposal and dissipation of the society. Absence of job satisfaction in an organizational setting leads to worker lethargy and reduced organizational commitment (Moser, 1997).

Job satisfaction has been linked both to situation factors and personal factors. Situation factors include job-related conditions such as pay, opportunities for promotion and working conditions, and characteristics such as task identity, task significance, skill variety, autonomy, and feedback (Heller, Judge \& Watson, 2002). According to Dormann and Zapt, (2001), personal factors include personality disposition, traits, self-esteem, motivation, and emotions. Positive factors such as high energy, pleasurable engagement, and enthusiasm are positively related to job satisfaction while negative factors such as distress, unpleasant engagement and nervousness are negatively related to job satisfaction

\subsection{Defining Emotional Intelligence}

Emotional intelligence is a psychological construct that has received the attention of many psychologists in recent time. Salovey and Mayer (1990) defines emotional intelligence as the ability to monitor one's own and others' emotions, to discriminate among them and to use the information to guide one's thinking and actions. Mayer and Salovey (1997, p. 401) refined their definition of emotional intelligence as "the ability to perceive accurately, appraise, and express emotion; the ability to access and/or generate feelings when they facilitate thought; the ability to understand emotion and emotional knowledge; and the ability to regulate emotions to promote emotional and intellectual growth". This concept emphasizes the importance of self-awareness and the ability to re-evaluate and balance a person's intellect and emotion within a typical daily life. Emotionally intelligent individuals use their emotions to engage in intelligent thought and also possess the ability to think intelligently about their emotions (Mayer \& Salovey, 1997; Mayer, Salovey, \& Caruso, 2000).

Emotional intelligence plays a great role in shaping individuals. Goleman (1999) explained that emotional intelligence creates passion, confidence, friendliness, motivation, pride and energy in individuals. The ability to transmit these same emotions to others offers emotionally intelligent people advantages over others in interpersonal and organizational contexts. Emotional intelligence focuses more on emotional problem solving, rather than on the social, political or verbal aspects inherent in the social intelligence construct (Mayer et al, 2000).

Definitions or models of emotional intelligence tend to be either ability based or a mixture of abilities and personality traits (Mayer et. al; 2000). The ability based model refers to emotional intelligence as a type of intelligence reflecting the ability to process emotional information (Mayer \& Salovery, 1997). In contrast, the mixed emotional intelligence model incorporates both ability factors and personality traits (Mayer, et al., 2000).

Emotional intelligence is an ability that involves the interchange of emotions and intelligence (Mayer, et. al., 2000). People that are emotionally intelligent possess a clear understanding of their feelings, and can restore their moods more 
quickly than those individuals with low levels of emotional intelligence (Ciarrochi, Chan \& Caputi, 2000).

\subsection{Job Satisfaction and Emotional Intelligence}

Research has examined relationships between emotional intelligence and job satisfaction. Most of the findings of the studies are mixed. A number of studies revealed weak to moderate relationships between trait emotional intelligence measures and job satisfaction (Carmeli, 2003; Vacola, Tsaousis \& Nikolaou, 2003; Kafetsios \& Loumakou, 2007). Wong \& Law (2002) observed a positive association between an ability based emotional intelligence and job satisfaction in employees and their managers. Kulshrestha and Sen (2006) found a positive correlation between high levels of emotional intelligence and subjective well-being among executives.

Bar-On (1997) sampled 314 participants from a variety of occupations and found that measures of emotional intelligence predicted a slightly significant relationship between total emotional intelligence scores and satisfaction. Platsidou (2010) found a positive relationship between emotional intelligence and job satisfaction and special education teachers. Guleryuz, Guney, Aydin, Asan (2008) found emotional intelligence to be significantly and positively related to job satisfaction and organizational commitment. Anari's (2012) revealed a positive significant relationship between emotional intelligence and job satisfaction among high school English teachers.

Salim, et.al. (2012) conducted a study on the role of emotional intelligence and job satisfaction among school teachers using 1200 primary and secondary school teachers. The result of the study showed a significant positive relationship between emotional intelligence and job satisfaction. Kafetsios and Zampetakis (2007) found emotional intelligence as an important personality-level predictor in teachers. Fasilizadeh, Oreyzi \& Nouri (2012) reported a positive significant relationship between emotional intelligence and job satisfaction. Najafi and Mousavi (2012) also reported a significant positive correlation between emotional intelligence and all dimensions of job satisfaction. Mousavi, Yarmohammadi, Nostrat and Tarasi (2012) studied the relationship between emotional intelligence and job satisfaction of Physics Education teachers in Iran. The results showed that there was a significant positive relationship between emotional intelligence and job satisfaction.

On the contrary, Donaldson-Feilder \& Bond (2004) found no association between emotional intelligence and job satisfaction of 290 workers in the United Kingdom. The contrasting relationship between emotional intelligence and job satisfaction that was reported by researchers is a gap that this study intended to fill.

\subsection{Self-Efficacy}

Teacher self-efficacy is a vital factor and a worthy variable in educational research (Woolfolk \& Hoy, 1990). Teacher efficacy is defined as a teacher's judgement of his/her own capability to bring about desired outcomes from students' engagement and learning, even among those students who may be difficult or unmotivated. A strong sense of efficacy enhances human accomplishment and personal well-being in many ways. According to Oyewumi, Ibitoye and Sanni (2012), people with high assurance in their capabilities approach difficult tasks as a challenge to be mastered rather than as threats to be avoided. Such an efficacious outlook fosters intrinsic interest and deep commitment. They heighten and sustain their efforts in the face of failure. They quickly recover from failure and setbacks. They attribute failures to insufficient effort or deficient knowledge and skills which are acquirable. They approach threatening structure with assurance that they can overcome them. Such efficacious outlook produces personal accomplishment, reduces stress and lower vulnerability to depression (Bandura, 2001). However, a teacher with low self-efficacy avoids difficult tasks which he views as personal threats. Such teacher usually has low aspirations and weak commitment to the goals they have set for themselves in their chosen profession.

Bandura (1994) stated that there are four main sources of a person's self-efficacy: mastery experiences, vicarious experiences, social (verbal) persuasion, and somatic and emotional states in judging one capability (physiological arousal). The first and most effective source is "mastery experience" or successes at tasks (p.2). Mastery experiences increase one's self-efficacy, while failures may inhibit its development.

The second source of self-efficacy is "vicarious experiences" provided by "social models" (p.3). People judge their self-efficacy by comparing with similar others. Observing the success of others similar to oneself contributes positively to self-efficacy. On the other hand, observing the failures of others similar to oneself decreases self-efficacy.

The third source of self-efficacy is "social persuasion" (p.3). Self-efficacy can be influenced if told by others that an individual "has what it takes to succeed" (p.3). Self-efficacy can also be diminished if told by others that an individual do not possess the skills for success. It is easier for social persuasion to decrease self-efficacy than increase it (Bandura, 
1994).

The final source of self-efficacy is "somatic and emotional states in judging one's capabilities" (p.3). This is how people react to situations whether physical or mental. "Somatic indicators of personal efficacy are especially relevant in domains that involve physical accomplishments, health functioning and coping with stressors" (Bandura, 199; p. 106).

Teachers that are highly self-efficacious have more motivation to remain in the teaching profession than teachers with low self-efficacy (Whittington, McConnell \& Knobloch, 2003). Less efficacious teachers are more likely to experience burnout and leave the profession (Bandura, 1993). Thus, secondary school teachers that have low teaching self-efficacy may find it very difficult to enjoy job satisfaction.

\subsection{Teacher self-efficacy and Job satisfaction}

Previous studies supported the influence of teachers' self-efficacy beliefs on the performance and motivation (Woolfolk, Rosoft \& Hoy, 1990; Bandura, 1997; Ross, 1998; Tschannen-Moran \& Hoy 2001; Woolfolk \& Davis 2006; Caprara, Barbaranelli, Stea, Malone, 2006). Self-efficacy also promotes a high level of commitment to the profession, collaborative relationship with colleagues and successfully contributing to the promotion of a rich and stimulating learning environment. (Coladarci, 1992; Imants \& Van Zoelen, 1999). Trentham, Silvern and Brogdon (1985) found that teachers' self-efficacy is related to teachers' job satisfaction and their competence as rated by school superintendents. Other studies also showed that teachers' self-efficacy affect and sustain teachers' job commitment and satisfaction (Caprara, Barbaranelline Borgogni, Petitta, Rubinacci, 2003; Ryan \& Deci 2000; Caprara, Barbarnelli, Steca, Malone, 2006). Telef (2011) investigated the relationship between the self-efficacy, job satisfaction, life satisfaction and burnout of teachers. Results indicated that self-efficacy has statistically significant positive relationship with teachers' job and life satisfactions.

\subsection{Occupational Stress}

Stress has been described as the phenomenon of strain experiences by an organism due to external pressure (Seyle, 1956). It is the non-specific response of the body to any demand. According to Luthans (1994), stress is the abnormal reaction that the organism displays against threatening environmental elements. It is a general term used for pressure that people are exposed to in life (Eres \& Atanasoska, 2011). There are two types of stress namely: eustress and distress (Fevre, Matheny \& Kolt, 2003). Eustress is often described as moderate and low stress levels and distress is the high level of stress experienced by individuals. Teachers who experience eustress would be able to meet job demands. This could contribute to increased quality of work life. On the other hand, teachers who experience distress may not be able to fulfill job demands and this may lead to decreased quality of work life (Newell, 2002; Fevre, et al, 2003; Leka, Griffiths \& Cox, 2004; Millward, 2005).

In the context of an organization, occupational stress is known as job stress or work stress. These terms are used interchangeably and they have the same meaning (AbuAIRub, 2004). Stress experienced by a teacher in the course of discharging his/her responsibilities is known as teacher stress. It is unpleasant emotions experienced by a teacher such as tension, frustration, anger and depression resulting from aspects of his work as a teacher (Kyriacou, 1987). Teachers have been described as an occupational group that functions under conditions of high stress (Malik, Nudler \& Meinhe, 1998). Smith and Bourke (2000), United Kingdom National Union of Teachers (2000) and United Kingdom Health and Safety Executive (2000) reported that two out of every five teachers were highly stressed as against one in every five in other occupations such as nursing, management, road haulage and security. Sources of stress among teachers include the following: strike, delay and irregular payment of salary, lack of infrastructural facilities, high cost of living, workload (Ofoegbu \& Nwandiani (2006).

\subsection{Relationship between Job Stress and Job Satisfaction}

The relationship between occupational stress and job satisfaction is well documented in the literature. Contrasting relationships were reported by researchers. Cooper, Rout, Faragher (1989) found in their study of general practitioners in England that job stressors were predictive of job dissatisfaction. In another study, Ismail, Yao, Yunus (2009) demonstrated that level of physiological stress has increased job satisfaction and level of psychological stress did not decrease job satisfaction. Moreover, Liu and Ramsey (2008) found that stress from poor working conditions had a strong influence on teachers' job satisfaction and noted that inadequate time for planning and preparation and a heavy teaching workload reduced satisfaction from teaching. In addition, Klassen and Chiu (2010) in their study reported that teachers 
with high overall teaching stress had lower job satisfaction. Sattar and Jamil (2004) conducted a research study to find the effects of job stress on job satisfaction of head teachers at elementary level. Sample of the study were thirty heads (fifteen male and fifteen female) of elementary schools of Lahole city. The results of the study showed that most of the head teachers at elementary level were experiencing high level of stress which negatively affected their job satisfaction.

It is evident from the literature review that many studies had examined various factors influencing job satisfaction among teachers but few of these studies looked into the impact of psychological factors. Even, the results of the available research are contradictory. Thus, there is need for more research to examine the relationship between psychological factors and job satisfaction in order to corroborate the existing ones. In addition, the researchers of the present study are not aware of any recent study that has addressed the contributions of emotional intelligence, job satisfaction and self-efficacy to teachers' job satisfaction in Ondo State, Nigeria.

\section{Research Questions}

The following research questions were raised for the study

1. What is the combined contributions of emotional intelligence, self-efficacy and occupational stress to the prediction of job satisfaction of secondary school teachers?

2. What is the relative contribution of emotional intelligence, self-efficacy and occupational stress to the prediction of job satisfaction of secondary school teachers?

\section{Methodology}

\subsection{Research Design}

This study adopted a survey research design in order to explore the predictions of job satisfaction from emotional intelligence, self-efficacy and occupational stress of teachers.

\subsection{Participants}

A total of 398 secondary school teachers [Male $=182,(45.7 \%)$; Female $=216(54.3 \%)$ ] randomly selected from Ondo State, Nigeria participated in the study. Stratified random sampling technique was used is selecting the sample. The participants' age ranged between 20 and 55 years, with a mean age of 37.54 and standard deviation of 9.66 . The teaching experience of the participants ranged from 1 to 35 years with a mean of 13.7 years and the standard deviation was 4.039. Out of the 400 copies of the questionnaires distributed, two were not properly filled and were discarded and not used for the analysis.

\subsection{Measures}

\subsubsection{Emotional Intelligence Questionnaire}

Emotional Intelligence Questionnaire developed by Schutte et al., (1998) was adopted for the study. The questionnaire consisted of 33 items with the range of responses from 1 ("I don't agree at all") to 5 ("I completely agree") and scores from 33 to 165 and the higher the score the higher the emotional intelligence. The psychometric properties of the EIQ are satisfactory. Cronsch's alpha was $0.83-0.87$; test re-test was 0.88 for male and 0.81 for female.

\subsubsection{General self-efficacy (GSE)}

The General self-efficacy (GSE) by Sherer, et al. (1982) was adopted for the study. This scale is a Likert format 17-item scale (examples of items include: "When I make plans, I am certain I can make them work", "I give up easily", "I am a self-reliant person", "I avoid facing difficulties"). The response format is a 5 point scale ( 1 = strongly disagree, 5 = strongly agree). Sum of item scores reflects general self-efficacy. The higher the total score is, the more self-efficacious the respondent. Sherer et al. developed the GSE scale to measure "a general set of expectations that the individual carries into new situations". The Sherer General Self Efficacy Scale (SGSES) has been the most widely used General Self Efficacy measure. Reviewing various organizational studies, Chen, et al. (2001) found internal consistency reliabilities of 
SGSES to be moderate to high ( $\alpha=.76$ to .89 ). The researcher of this study used test retest approach to determine the reliability of the instrument in Nigeria. The analysis yielded .81 reliability coefficient. This shows the instrument could be administered on Nigerian students. The promotion examination results of students in English and Mathematics were used to determine their academic performance.

\subsubsection{Job Satisfaction Scale (JSS)}

The job satisfaction scale was developed by Steers (1991). It is a 6-item scale on which respondents indicated their degree of agreement with the measure. The rating, which was a 5-point Likert pattern of Strongly Disagree $=1$, to Strongly Agree $=5$. The instrument has a coefficient alpha of 0.80 . The researchers conducted a pilot study in order to revalidate the instrument and a coefficient alpha of 0.91 was got for job satisfaction scale. The Job satisfaction scale was scored on a 5-point Likert pattern of Strongly Agree to Strongly Disagree. The items include, "I have the feeling of selffulfillment a person gets from being on my job". "I am satisfied with the opportunity for personal growth and development on my job".

\subsubsection{Occupation Stress Scale}

The Occupational Stress Scale (OSS) developed by Hassan and Hassan (1998) measures a variety of stressful job situations. Participants respond by indicating their level of agreeableness to each of the 60 -item statements using a fivepoint scale ranging from 1 (Never like me) to 5 (Always like me). The OSS has also demonstrated a high internal consistency (Cronbach a ranged from 0.79 to 0.87 ). The scale also has a test-retest reliability coefficient of 0.76 .

\subsection{Procedure}

All the participants for the study were administered the four instruments namely: emotional intelligence, self-efficacy, occupational stress and job satisfaction scales. The researchers carefully explained the essence of each scale to the teachers to avoid invalid responses. Enough time was given to the respondents to patiently fill the instruments.

\subsection{Data Analysis}

Data were analyzed using Pearson's Product Moment Correlation and Multiple Regression analyses in order to establish the relationship between the independent variables (emotional intelligence, self-efficacy, occupational stress) and dependent variable (Job satisfaction).

\section{Results}

Table 1 contains the descriptive statistics and inter-correlations among the study variables. As shown in the table, job satisfaction correlated with emotional intelligence $(r=0.263$; $P<0.005)$ and Self-efficacy $(r=0.264, P<0.05)$. A negative insignificant relationship was found between occupational stress and job satisfaction.

Table 1: Descriptive Statistic and Correlations among the Variables

\begin{tabular}{|l|c|c|c|c|c|c|c|}
\hline Variable & N & Mean & S.D & E.I & S.E & OS & J.S \\
\hline Emotional Intelligence (E.I) & 398 & 59.97 & 8.53 & 1 & & & \\
\hline Self-efficacy (S.E) & 398 & 37.89 & 5.31 & $.37^{\star}$ & 1 & & \\
\hline Occupational Stress (O.S) & 398 & 201.21 & 28.42 & .10 & $.27^{\star}$ & 1 & \\
\hline Job Satisfaction (J.S.) & 398 & 23.30 & 4.24 & $.26^{\star}$ & $.26^{\star}$ & -.09 & 1 \\
\hline
\end{tabular}

Note: $=\mathrm{P}<0.05(2-$ tailed $)$ 
5.1 Research Question 1: What is the combined contributions of emotional intelligence, self-efficacy and occupational stress to the prediction of job satisfaction of secondary school teachers?

Table 2: Multiple Regression Analysis on Independent \& Dependent Variables

$\mathrm{R}=.320$
$\mathrm{R}$-Square $=.102$
Adjusted R-square $=.095$
Standard Error $=4.036$
\begin{tabular}{|l|c|c|c|c|c|}
\hline Source of Variance & Sum of Squares & $\mathrm{df}$ & Mean square & $\mathrm{F}$ & Sig \\
\hline Regression & 730.205 & 3 & 243.402 & & \\
\hline Residual & 6417.333 & 394 & 16.288 & \multirow{2}{*}{14.944} & 0.000 \\
\hline Total & 7147.538 & 397 & & \\
\hline
\end{tabular}

Significant @ 0.05

Table 2 shows that there is linear positive relationship between the predictor variables (emotional intelligence, selfefficacy, occupational stress) and criterion variable (job satisfaction) among secondary school teachers. The result shows that emotional intelligence, self-efficacy and occupational stress made $10.2 \%$ prediction of job satisfaction. The standard error of 4.036 indicates that on the average, teachers deviated from true value by 4.036 limits of that measure. The analysis of variance for the multiple regression data yielded an F-ratio of 14.94 which was significant at $P<0.5$. The implication of this result is that the combination of the three predictor variables (emotional intelligence, self-efficacy and occupational stress) significantly predicted job satisfaction of secondary school teachers.

5.2 Research Question 2: What is the relative contribution of emotional intelligence, self-efficacy and occupational stress to the prediction of job satisfaction of secondary school teachers?

Table 3: Relative Contributions of Emotional Intelligence, Self-Efficacy and Occupational Stress to the Prediction of Job Satisfaction

\begin{tabular}{|l|c|c|c|c|c|}
\hline Predictor Variables & \multicolumn{2}{|c|}{ Unstandardized Coefficient } & Standard Coefficient & t & P \\
\hline & B & SED & $\boldsymbol{\beta}$ & & \\
\hline Constant & 11.276 & 2.055 & & 5.487 & 0.000 \\
\hline Emotional Intelligence & $9561 \mathrm{E}-02$ & 0.026 & 0.192 & 3.746 & 0.000 \\
\hline Self-Efficacy & 0.150 & 0.042 & 0.188 & 3.541 & 0.000 \\
\hline Occupational Stress & $3.207 \mathrm{E}-03$ & -0.007 & -0.021 & 0.434 & 0.665 \\
\hline
\end{tabular}

Table 3 above shows that emotional intelligence and self-efficacy had significant contributions to the prediction of job satisfaction. Emotional intelligence had the greatest effect $(\beta=0.192 ; t=3.746 ; P<0.05)$. Self-efficacy also had a significant effect $(\boldsymbol{\beta}=0.188 ; t=3.541 ; P<0.05)$. Occupational stress did not significantly predict job satisfaction $(\boldsymbol{\beta}=$ $0.021 ; t=0.434 . P>0.05$.

\section{Discussion}

Results of the present study revealed that emotional intelligence significantly predicted job satisfaction. This finding is consistent with Platsidou (2010) and Najafi and Mousavi (2012) who found a significant relationship between emotional intelligence and job satisfaction of employees. The effect of emotional intelligence on job satisfaction is well documented in the literature (Bar-On, 1997; Wong \& Law, 2002; Carmeli, 2003; Hasankhoyi, 2006; Guleryuz, et al., 2008; Kafetsios \& Loumakou, 2007; Kafetsious \& Zampetakis, 2007; Anari, 2012; Salim, et al., 2012; Mousavi et al, 2012). The contributions of emotional intelligence to job satisfaction can be easily explained bearing in mind that emotional intelligence components according to Hyde, Pethe and Dhar (2002) include: self-awareness, empathy, self-motivation, emotional stability, managing relations, integrity, self-development, value orientation, commitment and altruistic behaviours that are highly germane to job satisfaction and success. Indeed, intrapersonal and interpersonal skills, ability to regulate ones feeling and solve problems are fundamental to achieving satisfaction and success in a place of work. Additionally, persons with high emotional intelligence can appraise and control their emotions and that of others 
effectively. Consequently, they gain more control over the tasks they perform which in turn influence their self-efficacy, job success and satisfaction.

The result of this study is at variance with Donaldson-Feilder and Bond (2004) who found no association between emotional intelligence and job satisfaction among workers. The findings of Hendee (2002) and Villard (2004) were also not in harmony with the findings of the present study. One possible reason for such inconsistent results is the difference in the instruments used to measure emotional intelligence and job satisfaction.

In the present study, the relationship between self-efficacy and job satisfaction is significant. This finding is supported by the previous studies (Allinder, 1994; Caprara, Babaranelli, Bargogni, Pettitra et al 2003, Caprara, Babaranelli, Bargogni, Steca, 2003, Caprara, Babaranelli, Steca \& Malone, 2006; Bandura, 2009; Oyewumi, Ibitoye, Sanni, 2012) who reported significant relationship between self-efficacy and job satisfaction. The outcome of this study could be due to the fact that self-efficacy ultimately determines how an individual behaves, thinks and becomes motivated to be involved in a particular task. Individuals with high self-efficacy tend to behave more positively, think more creatively which also interacts with motivation. Consequently, such teachers are relatively more satisfied with their jobs.

Another possible reason for this finding is that individuals with high level of self-efficacy have the ability to effectively handle various tasks, obligations and challenges related to their professional role. Thus, it is not surprising that a significant positive relationship was found between self-efficacy and job satisfaction among teachers.

The study also found a negative insignificant relationship between occupational stress and job satisfaction among participants. This result is consistent with previous research outcomes (Borg, Riding \& Falzon, 1991; Chaplin, 1995; Sattar \& Jamil, 2004; De Nobile \& McCormick, 2005; Chaudhry, 2012; Klassen \& Chiu, 2012). This is not surprising because stress occurs when workers perceive an imbalance between their work demands and their capability to meet these demands. It is a harmful physical and emotional response to conflicts between job demands on employee and the amount of control such employee has over meeting these demands. According to Schwab and Iwanlacki (1982), occupational stress can lead to a variety of negative outcomes, including emotional exhaustion, feeling of depersonalization and a sense of failure with one's personal accomplishment. Indeed, the above mentioned psychological outcomes of stress could lead to job dissatisfaction among teachers.

\section{Implications for Educational Transformation in Africa}

This study revealed that emotional intelligence significantly predicted job satisfaction of secondary school teachers. Thus, emotionally intelligent teachers experience job satisfaction and their counterparts that are not emotionally intelligent would likely experience job dissatisfaction. Evidence in the literature revealed that job dissatisfaction among teachers leads to absenteeism from schools, lack of commitment, turnover intensions, aggressive behaviour towards colleagues and learners and psychological withdrawal from work among teachers which are detrimental to educational transformation. Thus, it is important for school administrators, educational and counselling psychologists to use appropriate psychological interventions to enhance emotional intelligence among secondary school teachers. If emotional intelligence training is well manipulated, teachers would acquire some abilities and skills that would promote teachers' job satisfaction and quality education in Africa. These skills include:

i. interpersonal abilities (awareness of oneself and an understanding of one's emotions, and ability to set and achieve personal goals);

ii. interpersonal skill (awareness of others emotions, feelings and needs, as well as the ability to establish and maintain mutually satisfying relationship);

iii. Stress management (the ability to effectively manage and control emotions);

iv. adaptability (ability to realistically and flexibly cope with immediate situation and effectively solve problem as they arise); and

v. general mood (optimistic and positive outlook combined with a feeling of happiness and contentment with oneself, others and life in general).

If teachers are well trained to develop these abilities, they will likely experience better job commitment and satisfaction in their teaching profession. Consequently, educational system in Africa will be transformed.

The outcome of this study also revealed that self-efficacy is a good predictor of job satisfaction. This suggests that self-efficacy is an important determinant of job satisfaction among secondary school teachers. Hence, earnest efforts should be made by governments and counselling psychologists to enhance self-efficacy of teachers for the purpose of transforming education in Nigeria and Africa in general. Teachers with high level of self-efficacy beliefs are more likely to create and promote conditions and interpersonal networks that nourish and sustain work satisfaction. In addition, the 
recruitment policies and procedure should be structured in such a way that consideration would be given to applicants who demonstrate high levels of teaching self-efficacy. This seems to be particularly important today in African countries where teachers' job satisfaction is often at risk due to many new responsibilities of teachers and low external rewards for them. In this context, it is likely that teachers' perceived sense of competence is a primary source of intrinsic motivation and satisfaction. Indeed, there may be some teachers who feel efficacious, but dissatisfied with their jobs. These cases are quite unusual. Thus, gathering together efficacious teachers could lead to higher satisfaction more than gathering together teachers who doubt their capacities.

This study also revealed that occupational stress was not a significant predictor of job satisfaction. Even the relationship that was found between the two variables was negative. The implication of this finding is that high level of stress would result in job dissatisfaction among teachers. Thus, for teachers to effectively carry out their responsibilities in schools despite their increased workload, they should be exposed to various stress management strategies and coping mechanisms taught in counselling psychology. If physiological and psychological stresses are well managed, the capability of teachers to cope with occupational stress will strongly increase and this may lead to higher positive attitudinal and behavioral outcomes (e.g. performance, satisfaction, commitment, and positive moral values).

Although this study did not examine all the possible psychological correlates and predictors of job satisfaction among teachers, it nevertheless provides an empirical insight to the job phenomenon among secondary school teachers in Nigeria.

\section{References}

AbuAlRub, R. F. (2004). Job stress, job performance and social support among hospital nurses. Journal of Nursing Scholarship, 36(1), 73-78.

Adetayo, J. O (2008). Level of teachers' job satisfaction in Ogun secondary schools. International Journal of Emotional Psychology and Sport Ethics, 10, 208-216.

Adeyemo, D.A. (1986). Correlates of job satisfaction among primary secondary school teachers in Oyo State. Unpublished M. Ed Thesis, University of Ibadan, Ibadan.

Adeyemo, D.A. (1996). The relative influence of sex and working experience on the job satisfaction of primary school teachers in Ibadan. The Primary School Educators, 1(1), 86-89.

Adeyoju, C.A. (1999). Training, value and adjustment among primary and post primary school teachers. Evaluation in Africa. Ibadan; Stirling Holden Publisher.

Ajayi, A.O. (1998). Resources utilization: The mandate of education managers. Faculty Lecture, Faculty of Education, University of Ibadan, Ibadan.

Ajayi, S.A. (1981). Job satisfaction and commitment among Nigeria University Teachers, Unplished Ph.D. thesis, University of Ibadan, Ibadan.

Akomolafe M.J. \& Olatomide O.O. (2013). Job satisfaction and emotional intelligence as predictors of organizational commitment of secondary school teachers. Ife PsychologIA, 21(2).....

Allinder, R. (1994). The relationship between efficacy and the instructional practices of special education teachers and consultants. Teacher Education and Special Education, 17, 86-95.

Anari, N.N. (2012) "Teachers: emotional intelligence, job satisfaction, and organizational commitment", Journal of Workplace Learning, $24(4), 256-269$.

Arches, J. (1999). Social structure, burnout, and job satisfaction. Social Work, 36, 193-272.

Bandura, A. (1994). Self-Efficacy. In V.S. Ramachaudran (Ed.), Encyclopedia of human behavior, 4, 71-81.

Bandura, A. (1997). Self-efficacy: The exercise of control. New York: Freeman.

Bandura, A. (2001). Social cognitive theory: An agentic perspective. Annual Review of Psychology, 52, 1-26.

Bandura, A. (2009). Social cognitive theory of mass communication. In J. Pryant and M. Boher (Eds) Media Effects Advance In Theory And Research (2nd edition,pp94-124). Mahwah, NJ: Lawrence Erlbaum.

Bandura, A. 1993. Perceived self-efficacy in cognitive development and functioning [Electronic Version]. Educational Psychologist 28(2), $117-148$.

Bar-On, R. (1997). The Bar-On Emotional Quotient Inventory (EQ-i): A Test of Emotional Intelligence. Toronto, Canada: Multi-Health Systems.

Borg, M. G., Riding, R. J. \& Falzon, J. M. (1991). Stress in teaching: a study of occupational stress and its determinants, job satisfaction and career commitment among primary schoolteachers, Educational Psychology, 11, 1, 59-75.

Borzaga, C., \& Tortia, E. (2006). Worker motivations, job satisfaction, and loyalty in public and nonprofit social services. Nonprofit and Voluntary Sector Quarterly, 35, 225-248.

Caprara, G. V., Barbaranelli, C., Borgogni, L., Petitta, L., \& Rubinacci, A. (2003). Teachers', school staff's and parents' efficacy beliefs as determinants of attitude toward school. European Journal of Psychology of Education, 18, 15-31.

Caprara, G. V., Barbaranelli, C., Steca, P., Malone, P. S. (2006). Teachers' self-efficacy beliefs as determinants of job satisfaction and 
students' academic achievement: A study at the school level. Journal of School Psychology, 44, 473-490.

Carmeli, A. (2003). The relationship between emotional intelligence and work attitudes, behavior and outcomes. Journal of Managerial Psychology, 18, 788-813.

Chaplin, R.P. (1995). Stress and Job satisfaction: A study of English primary school teachers. Education. Psychol. 15, 473-489.

Chaudhry, A. Q. (2012). The relationship between occupational stress and job satisfaction: The case of Pakistani Universities. International Education Studies, 5(3), 212-221.

Ciarrochi, J.V., Chan, A.Y.C., \& Caputi, P. (2000). A critical evaluation of the emotional intelligence construct. Personality and Individual Differences, 28, 539-561.

Coladarci, T. (1992). Teachers' sense of efficacy and commitment to teaching. Journal of Experimental Education, 60, 323-337.

Cooper C, Rout U, Faragher B. (1989). Mental health, job satisfaction, and job stress among general practitioners. Br Med J. 298(6670), 366-370.

De Nobile, J. J. \& McCormick, J. (2005), Job satisfaction and occupational stress in Catholic primary schools, a paper presented at the Annual Conference of the Australian Association for Research in Education, Sydney, November 27th-December 1st, 2005, available online at: http://www.aare.edu.au/05pap/den05203.pdf

Donaldson-Fielder, E.J. \& Bond, F.W. (2004). The relative importance of psychological acceptance and emotional intelligence to workplace well-being. Br. J. Guidance and Counselling, 32, 187-203.

Dormann, C. \& Zapf, D. (2001). Job satisfaction: A meta-analysis of stabilities. Journal of Organizational Behavior, 22,483-504.

Erdoğan, İ. (1994). İşletmelerde davranış. Beta Yayınları, İstanbul.

Eres, F. \& Atanasoska, T. (2011). Occupational Stress of Teachers: A Comparative Study Between Turkey and Macedonia, International Journal of Humanities and Social Science Vol. 1(7), 59-65

Fasihizadeh, N., Oreyzi, H., \& Nouri, A. (2012). Investigation of positive affect and emotional intelligence effect on Job satisfaction among oil refinery personnel of Isfahan. Interdisciplinary Journal of Contemporary Research in Business, 4(2), 355.

Fevre, M.L., Matheny, J., \& Kolt, G. S. (2003). Eustress, distress and interpretation in occupational stress. Journal of Managerial Psychology, 18(7), 726-744.

George, J.M., \& Jones, G.R. (2008). Understanding and managing Organizational Behavior. (Fifth Edition). Upper SaddleRiver: New Jersey, Pearson Prentice Hall.

Gesinde, A.M. \& Adejumo, G. O. (2012). Job satisfaction status of primary school teachers in Ota, Nigeria, European Journal of Educational Studies, 4(1), 11-18

Ghazzawi, I. A. (2008). Job Satisfaction Antecedents and Consequences: A New Conceptual Framework and Research Agenda. The Business Review, Cambridge, 11(2), 1-10.

Ghazzawi, I., \& Smith Y. (2009). Crafting the Whole Employee: Job Satisfaction, Job Commitment, and Faith-A New Conceptual Framework and Research Agenda. The Business Review, Cambridge. 12(2), 300-309.

Goleman, D. (1999). Emotional competence. Executive Excellence, 16 (4), 19-29.

Guleryuz, K., Guney, S., Aydin, E.M., \& Asan, O. (2008). The mediating effect of job satisfaction between emotional intelligence and organizational commitment of nurses: A questionnaire survey. International Journal of Nursing Studies, 45(11), 1625-1635.

Hasankhoyi,(2006). MSc Thesis, Al-Zahra University, (Tehran, Iran, 2006).

Hassan, T. \& Hassan, M. (1998). Development and validation of occupational stress scale. Unpublished monograph, Department of Educational Foundation and Management, Olabisi Onabanjo University, Ago-Iwoye, Nigeria.

Heller, D., Judge, T., \& Watson, D. (2002). The confounding role of personality and trait affectivity in the relationship between job and life satisfaction. Journal of Organizational Behavior, 23, 815-835.

Hendee, S. S. (2002). Measurement of differences in emotional intelligence and job satisfaction of practicing chefs and culinary educators as measures by the Mayer-Salovey-Curuso emotional intelligence test and Spector's job satisfaction survey. Dissertation Abstracts International Section A. Humanities and Social Sciences, 63, 916-918.

Hyde, A., Pethe, S., \& Dhar, U. (2002). Emotional intelligence scale (EIS). Lucknow: Vedant Publications.

Imants, J., \& Van Zoelen, A. (1995). Teachers' sickness absence in primary schools, school climate and teachers' sense of efficacy. School Organization, 15, 77-86.

Ismail, A. Yao, A. \& Yunus, N.K.Y. (2009). Relationship between occupational stress and job satisfaction: An empirical study in Malaysia. The Romanian Economic Journal, 34(4), 3-29.

Kafetsios, K. \& Zampetakis, L. A. (2008). Emotional intelligence and job satisfaction: Testing the mediatory role of positive and negative affect at work. Personality and Individual Differences, 44, 712-722.

Kafetsios, K., \& Loumakou, M. (2007). A comparative evaluation of the effects of trait emotional intelligence and emotion regulation on affect at work and job satisfaction. International Journal of Work Organization and Emotion, 2(1), 71-87.

Khanna, M. J. (2010). A comparative study of leadership behaviour of principals in relationto job satisfaction of teachers in government and non-government schools of U.T. Retrieved 27th July, 2010 from http://www.academicleadership.org/empirical_research/index/shtml

Kim, S. (2004). Factors affection state government information technology employee turnover intentions. American Review of Public Administration, 35, 137-156.

Klassen, R. M., Chiu, M. M. (2010). Effects on teachers' self-efficacy and job satisfaction: Teacher gender, years of experience, and job stress. Journal of Educational Psychology, 102(3), 741-756.

Kulshrestha, U. \& Sen, C. (2006). Subjective well-being in relation to emotional intelligence and locus of control among executives. 
Journal of the Indian Academy of Applied Psychology, 32(2), 129-134.

Kyriacou, C. (1987), Teacher stress and burnout: An international review. Educational Research, 29, 146-152.

Leka, S., Griffiths, A., \& Cox, T. (2004). Work organization and stress. Nottingham: UK. World Health Organization.

Liu, X. S., \& Ramsey, J. (2008). Teachers' job satisfaction: Analyses of the Teacher Follow-Up Survey in the United States for 2000 2001. Teaching and Teacher Education, 24, 1173-1184.

Locke, E.A. (1976). The nature and course of job satisfaction. In Dunnettee, M.D. Handbook of Industrial and Organizational Psychology, 1319-28. Chicago: Rand McNally \& Co.

Luthans, F. (1994). Organizational behavior. Boston: Mc Graw Hill Publishing.

M. Shahnawaz, and H. Jafri, Job attitudes as predictor of employee turnover among stayers and leavers/hoppers. Journal of Management Research, 9(3), 159-166. 2009.

Malik, J.L., Mudler, R.O. \& Meinhe D.L. (1998). The Effects of Teaching Experience and Grade Level Taught on Teacher Stress: A Listrel Analysis. Teaching and Teacher Education, 7, 57.

Mayer, J. D., \& Salovey, P. (1997). What is an emotional intelligence? In P. Salovey \& D. Sluyter (Eds.), Emotional development and emotional intelligence: Implications for educators. New York: Basic Books.

Mayer, J. D., Salovey, P., Caruso, D. (2000c). Models of emotional intelligence. In R. J. Sternberg (Ed) Handbook of intelligence. (pp. 396-420). New York, NY, US: Cambridge University Press.

Millward, L. (2005). Understanding occupational and organizational psychology. Thousand Oaks, California: Sage Publications.

Moser, K. (1997). Commitment in organizations. Psychologies, 41 (4), 160-170.

Mousavi, S.H., Yarmohammadi, S., Nosrat, A.B. \& Tarasi, Z. (2012). The relationship between emotional intelligence and job satisfaction of physical education teachers. Annals of Biological Research, 3(2), 780-788

Najafi, M. \& Mousavi, S. (2012). Studying the Effect of Emotional Quotient on Employee's Job Satisfaction (The Case of Isfahan University of Medical Sciences). Interdisciplinary Journal of Contemporary Research in Business, 4(2), 343

Newell, S. (2002). Creating the healthy organization: Well-being, diversity \& ethics at Work. London: Thomson Learning.

Ofoegbu, F. \& Nwandiani, M. (2006). Level of perceived stress among lecturers in Nigerian Universities. Journal of instructional psychology, 33 (1), 66-74

Oyewobi, L.O., Suleiman, B. \& Muhammad-Jamil, A. (2012). Job Satisfaction and Job Commitment: A Study of Quantity Surveyors in Nigerian Public Service. International Journal of Business and Management, 7(5), 179-192.

Oyewumi, A, Ibitoye, H.O., \& Sanni, O. B. (2012). Job Satisfaction and Self-Efficacy as Correlates of Job Commitment of Special Education Teachers in Oyo State. Journal of Education and Practice, 3(9), 95-103.

Platsidou, M. (2010). Trait emotional intelligence of Greek special education teachers in relation to burnout and job satisfaction. School Psychological Int., 31, 60-76.

Robbins, S.P., \& Judge, T. A. (2009). Organizational Behavior. (Thirteenth Edition). Upper Saddle River: New Jersey, Pearson Prentice Hall.

Ross, J. A. (1998). The antecedents and consequences of teacher efficacy. In J. Brophy (Ed.) Advances in Research on Teaching. Vol. 7 (pp. 49-74). Greenwich, CT: JAI Press.

Rue, L.W., \& Byars, L.L. (2005). Management: Skills and Application (Eleventh Edition). New York: New York. The McGraw Hill Companies.

Ryan, R. M., \& Deci, E. L. (2000). Self-determination theory and the facilitation of intrinsic motivation, social development, and wellbeing. American Psychologist, 55, 68-78.

Salim, S.S.S., Nasir, R., Arip, M.A.S.M. \& Mustafa, M.B., (2012). The Role of Emotional Intelligence on Job Satisfaction among School Teachers. The Social Sciences, 7: 125-129.

Salovey, P. \& Mayer, J .D. (1990).Emotional Intelligence, Imagination, Cognition, and Personality, 9, 195-211.

Sattar, K., \& Jamil, M. (2004). A study of effects of stress on job satisfaction among elementary head teachers. University of the Punjab, Lahore.

Schutte, N.S., Malouff, J.M. Hall, L.E. Haggerty, D.J., Cooper, J.T. Golden, C.J. \& Dornheim, L. (1998). Development and Validation of a Measure of Emotional Intelligence. Personality and Individual Differences, 25, 167-177.

Schwab, R.L., \& Iwanicki, E.F. (1982). Who are our burned out teachers! Educational Research Quarterly, 7(2), 5-16.

Selye, H. (1956). The stress of life. NY: McGraw-Hill.

Sherer, M., Maddux, J. E., Mercandante, B., Prentice-Dunn, S., Jacobs, B., \& Rogers, R.W. (1982). The Self-Efficacy Scale: Construction and validation. Psychological Reports, 51, 663-671.

Smith, B \& Bourke, S (2000). Teacher Stress: Examining a Model Based on Context, Workload and Satisfaction. Teacher and Teacher Education, 8(1).

Spector, P. E. (1997). Job satisfaction: application, assessment, cause, and consequence. Thousand Oaks, CA: Sage.

Spector, P. E. 2000. Industrial and organizational psychology: Research and practice (2nd ed.) New York: John Wiley and Sons

Steers, R. M. (1991). Introduction to organizational behavior, 4th edition, Harper, New York, Collins Publishers Inc.

Steyn, G.M. (1992). Enkele beinvloedingsfere in onderwysberoepsbevrediging en beroepsontevredenheid. Tydskif vir Geesteswetenskape, 32, 312-321.

Telef, B.B. (2011). The study of teachers' self-efficacy, job satisfaction, life satisfaction and burnout, Elementary Education Online, 10(1), 91-108.

Trentham, L., Silvern, S., \& Brogdon, R. (1985). Teacher efficacy and teacher competency ratings. Psychology in the Schools, 22, 
343-352.

Tschannen-Moran, M. \& Hoy, A.W. (2001). Teacher efficacy: Capturing an elusive construct. Teaching and Teacher Education, 17, 783805.

UK Health and Safety Executive (2000). Tackling Work-Related Stress: A guide for Employees. UK Publications.

UK National Union of Teachers (2000). Stress 2000*. United Kingdom. NUT Publications.

Vacola, M., Tsaousis, I., \& Nikolaou, I. (2003). The role of emotional intelligence and personality variables on attitudes toward organizational change. Journal of Managerial Psychology, 19(2), 88-110.

Villard, J., (2004). Determining the relationship between job satisfaction of county extension unit employees and the level of emotional intelligence of extension county chairs. ProQuest Information and Learning Company, MI 48106-1346.

Whittington, M. S., McConnell, E. A., \& Knobloch, N. A. (2003). Teacher efficacy of novice teachers in agricultural education at the end of the school year. Proceedings of the 30th Annual National Agricultural Education Research Conference, Orlando, FL, $204-215$.

Wong, C. S., \& Law, K. S. (2002). The effects of leader and follower emotional intelligence on performance and attitude: An exploratory study. The Leadership Quarterly, 13, 243-274.

Woolfolk How, A. \& Davis, H.A. (2006). Teaching self-efficacy and its influence on the achievement of adolescents. In F. Pajares \& T. Urdan (Eds.), Self-efficacy of adolescents (pp. 117-137), Greenwich, Connecticut: Information Age Publishing.

Woolfolk, A. E., \& Hoy, W. K. (1990). Prospective teachers' sense of efficacy and beliefs about control. Journal of Educational Psychology, 82, 81-91.

Woolfolk, A. E., Rosoff, B., \& Hoy, W. K. (1990). Teachers' sense of efficacy and their beliefs about managing students. Teaching and Teacher Education, 6, 137-148.

Wright, B. E., \& Davis, B. S. (2003). Job satisfaction in the public sector: The role of the work environment. American Review of Public Administration, 33, 70-90. 